\title{
The Mythopoetic Study of Mask in Euripides's Play Medea: A Sign of Plurality
}

\author{
Bakhtawar Alishba, Muhammad Adnan \\ Pakistan
}

\begin{abstract}
This research explores the mythopoeia nature of mask in Euripides's play Medea. The use of mask in the play Medea is plural as it functions both objectively and subjectively. The subjective study of mask involves the study of character's mind and the objective function entails the use of mask as a visual tool in the play Medea. To study the nature and the function of mask, the researcher draws on Pirandello and Derek Walcott's concept of mask respectively. The researcher examines how the idea of the reworking of myth is used by the playwright in order to unpack the motifs of the play. Furthermore, mask is embedded in the language of the characters in general and the protagonist of the play, Medea in particular. The findings of this research thro $w$ light upon mask as the most vital and viable element in the play that unmasks the ironical and hypocritical behavior of the characters universally and the protagonist, Medea specifically. The researcher accentuates that people conceal their real motives behind the mask.
\end{abstract}

Keywords: Mask, Myth, Language, plural, Motives, Medea, Pirandello, Derek Walcott, Motifs, mythopoetic

\section{RESEARCh QUESTIONS}

What is mask?

What are the various types of mask?

What is the subjective function of mask in Euripides's play Medea?

What is the objective function of the mask as visual tool in the drama?

What is the mythopoetic significance of the mask?

\section{FRAMEWORK AND METHODOLOGY}

To conduct the study, textual evidences are collected to explore and analyze the mythopoetic nature of mask in the Greek play Medea. The research is qualitative in nature. The researcher draws on the theory of mask given by modern dramatist Pirandello in his plays, Derek Walcott's concept of mask presented in Dream on Monkey Mountain and the nature of Trance which is discussed in IMPROimprovisation and the theatre by Keith Johnstone in order to understand the idea of mask. The researcher has structured his argument in two phases. First phase deals with objective perspective of mask whereas second phase encircles subjective perspective of mask. In the first phase, to study the subjective approach of mask, the researcher deploys Pirandello's concept regarding the use of mask. According to Pirandello, mask is a tool to conceal the reality. His works are concerned with the concept of mask in its different aspects. He deploys mask as a tool to express social, psychological and philosophical concerns. In addition, he indicates the duality of the characters, character mask, and conflict between appearance and reality. Similarly, Keith johnstone in his book IMPRO-Improvisation and the theatre discusses the nature of trance for the exploration of mask. According to him, "in a Trance state people are more in touch and appear to be more observant". In the second phase of the research, the study drawing upon Derek Walcott's perspective, explores the objective approach of mask. He refers to mask as a "verbal metaphor matched by a visual symbol to be read as a symbol of self deception and false identity". Mask is in fact a useful prism through which the tensions, contradictions and questions that beset the people come into existence. He further says that "Mask is a paralinguistic projection of a state of mind and brings into relief the thematic concern of the works of art'. 


\section{LiTERATURE REVIEW}

Many studies have been conducted to explore and analyze the concept of mask, its origin and its use in theatrical performance in accordance to the viewpoints of modern dramatists. Different researchers have studied the nature and function of mask and its different aspects in qualitative as well as in quantitative research. In a paper The psycho-political Mobilization of the Mask in Dream on Monkey Mountain by Derek Walcott, Iffat Sayeed, under the perspective of the mask as a visual tool by Derek Walcott, examines how mask provides a symbolic and metaphorical study of the conflict between white self and black others. She also explores the way in which the mask functions as an operatic reference that brings into greater prominence the themes of violence, racism embedded in the text of the play.

In another paper Beyond the Mask: A Study in the Functions of the Mask in W.B Yeats's The Dreaming of the Bones, Luigi Pirandello's Henry IV and Jean Genet's The Blacks, Amaal Jassim explores the presence of mask in the works of modern dramatists and expresses that human beings possess diverse layers of mask in order to fulfill their personal motive. He studies the concept of mask in accordance to Pirandello who unfolds that beyond the mask is a face of psychologically wounded man whereas in Genet's view the mask, the artificial appearance becomes the essence while Yeats pinpoints the theatrical functions of the mask. Amaal in his research provides the gist of the concept of mask in various aspects.

Furthermore, In an International Journal of Sociology and Anthropology, David Roy in a research paper titled Masks and cultural contexts drama education and Anthropology, studies mask as an aspect of semiotic identity in the society and points out that mask have an audience whether in entertainment or ritual. He concludes that in drama and the theatre mask has greater importance and serves as training tool for performance.

Moreover, Amy Jacobson in his thesis entitled In Hiding Behind the Mask of Contradiction: A Study of Mardi Gras and Race in New Orleans explores the racial conflict in a society where white and black reside together and issues regarding identity are found in Orlean where people wear paradoxical mask. He pinpoints that mask paves way to avoid the bloodshed when duel is provoked between self and the others.

The researcher's contribution is to study Euripides's reworking of myth of the myth of Jason and Medea in the form of Greek play Medea in the framework of the mythopoetic nature of mask based on modern theorists of mask. Pirandello and Derek Walcott explore the nature and function of mask in terms of subjective and objective approach respectively. The researcher through their perspective pinpoints that mask unmasks the deceptive nature of the characters in general and the protagonist of the play, Medea in particular. The use of mask also helps the playwright Euripides to unfold the motifs of the play Medea such as revenge, deception and hatred.

\section{Textual Analysis}

Euripides's Medea revolves around the central character Medea, who is the protagonist of the play. In the beginning of the play, she curses her husband for breaking the promises of not getting marriage to another lady. She decides to take revenge. She appears to be a cunning lady, who apparently pretends to be the well wisher of her husband, but inwardly having the intention to destroy him. She cleverly manipulates her husband and his bride. She skillfully deploys her children as a tool to kill her husband and his wife. She intends to gift a dress to the bride. She poisons the gift; as a result the bride is died. She also kills her children in order to give severe pain to her husband. She desires to see the deprivation of her husband. At the end, she shifts to another state after fulfilling her plot.

Mask is defined in various perspectives in the works of modern dramatists. According to Pirandello, a modern playwright, mask is a device as old as the drama itself. He sheds light on the subjective approach of mask. According to him, "Mask is a tool to conceal the reality or it is an appearance of false identity". He sets out to stripe these masks, to tear off these disguises, the conventional costume and to get the naked truth. Reality is not necessarily to be hidden behind a single mask since for him everything is masked and beneath the mask is the physical presence of the steady ache of suffering humanity. The subjective approach of mask involves the study of character's mind. It can be tackled through the psychological makeup of the characters in general and through their language in particular. Similarly, It can be observed through the Greek play Medea. The marriage between mask and the language of the characters is highlighted by the playwright Euripides. The protagonist of the 
play Medea has deployed the mask. It is unmasked through her language. Inwardly, she has intention to take revenge from her husband, Jason, but outwardly she pretends to be the well-wisher for others. Her mask is embedded in her language. Her discourse is changed when she confronts her husband's father in law, Creon, who decides to banish her out of fear that she might kill his daughter. She appeals him to allow her to stay for one day in Corinth so she might plan where she has to go. Their conversation reflects the idea of the mask. As they utter.

CREON: Go, you poor wretch, take all my troubles with you! Go!

MEDEA: I know what trouble is; I have no need of more.

CREON: why will you not get out?

MEDEA: This one day let me stay, to settle some plan for my exile, make provision for my two sons, since their own father is not concerned to help them. Show some pity: you are a father too, you should feel kindly towards them. For myself, exile is nothing. I weep for them. Their fate is very hard.

It illustrates the idea of mask being deployed by Medea. Apparently, she expresses her intention to make some plans for her departure, where she has to go after being exiled. Inwardly, she is planning how to be successful in her effort to kill her husband and his bride. Throughout the play, her language reflects the mask. The playwright proceeds language as a metaphor of mask. The Diverse layers of mask are being unmasked through the language of the characters in general and the protagonist of the play, Medea in particular.

On the other hand, Derek Walcott focuses on the objective approach of mask. He elucidates mask as a "verbal metaphor matched by a visual symbol to be read as a symbol of self-deception and false identity". Bestowing to him, mask is the visual, metaphoric representation of the duality between the self and the others. It can also be examined in the play Medea. The protagonist, Medea speaks in metaphoric language. It reflects her false identity. She shifts her focus and it is analyzed through her language. Firstly, she appears to be a wife then mother. Her quest of taking revenge converts her into a murderer. As she utters.

MEDEA: A bad predicament all around-yes, true enough; but don't imagine things will end as they are now. Trials are yet to come for this new wedded pair; Nor shall those nearest to them got off easily.

Her dialogue contains an image such as "Trial". It suggests hard time is to come. Mask is embedded in her language and it shows duality in her character. Similarly, there is conversation between Medea and her husband. It is replete with number of symbols which symbolize the idea of mask.

JASON: you sent for me now I have come. Although you hate me, I am ready to listen. You have some new request what is it?

MEDEA: jason I ask you to forgive the things I said.you must bear with my violent temper; you and I share many memories of love.i have been taking myself to task. You are a fool, I have told myself, you are mad, when people try to plan things for the best, to be resentful and pick quarrels with the king nd with your husband; what he is doing will help us all.His wife is royal; her sons will be my sons's brothers. Why not throw off your anger? What is the matter, since I have two children still to care for; and I know we came as exiles and our friends are few enough. When I consider this I saw my foolishness, I saw how useless anger was. So now I welcome what you have done. The folly was all mine. I should have helped you in your plans, made it my pleasue to get ready your marriage bed, attend your bride But we women are what we are. Showing folly for folly, I give in; I was wrong just now, I admit.

There are number of images in Medea's dialogue such as fool, quarrels, anger, plan, marriage bed. All reflect a disguise, which she applies to fullfill her internal wish. Anger and quarrels symbolize the hatred whereas, fool and marriage bed are symbols of cunningness. So, images in her discourse become the visual, metaphoric representation of her false identity. Her language foreshadows her plotting to take revenge. The image of 'Plan' itself mirrors the mask. She does not bother to injure others. She is ready to make the plans of destroying others. So, from the beginning of the play to the end, there are number of metaphors and images which directly refer to the mask as visual tool.

In .addition, Keith johnstone in his book IMPRO-Improvisation and the theatre discusses the nature of trance, which is compulsory in order to understand the idea of mask. He considers Trance is a state in which people are in more touch and appear to be more observant. It can also be observed in the 
play Medea. The protagonist Medea appears in her trance state. She is aware of what she speaks. Her anger comes out of her through her verbal discourse and she gets relief for some time. Fire is burning inside her and she wants to cease it by avenging her husband and his wife. It can be seen through her verbalization. She is conscious of what she has to do. Her dialogue mirrors her consciousness.

MEDEA: he shall never see alive again the sons he had from me. From his new bride he never shall breed a son; she by my poison, wretched girl, must die a hideous death. Let no one thing of me as humble or weak or passive. Let them understand I am of a different kind, dangerous to my enemies, loyal to my friends. To such a life glory belongs.

The above utterance unpacks that she is passionate enough to cease the fire burning inside. She decides to kill her children in order to wound her husband. Her sole aim is to pacify her anger. Here anger becomes the metaphor of revenge. Her trance state is the manifestation of her internal wish to avenge her husband who deceives her and gets marriage to other woman.

Furthermore, the concept of masking has been used for centuries. According to Pirandello, masking is in fact a process in which an individual changes his/her identity for personal gains and conceals the emotions. There are various types of masks. These masks include ritual masks, protection masks, disguise masks and entertainment masks. The nature and function of mask varies from one to another. Firstly, Ritual mask reveals the idea of old times. It is used in ceremonies and also uncovers the idea of myth. Such as the myth of Adam and Eve who were deceived by Satan. It also gave birth to the concept of Revenge. Every myth deals with the idea of taking revenge. Similarly, Euripides's Medea is alternative narrative of myth of Jason and Medea. It packs the themes of revenge, hypocrisy and hatred. Secondly, Protection mask is used to protect oneself from the others. The protagonist, Medea in this play deploys protection mask, when she heard the news of being banished from C Corinth. She asks for one day to make some plan about her save departure. Thirdly, Disguise mask is used to injure others in order to fulfill the personal motives. It is largely found the Euripides's play. Medea, the protagonist disguises herself to accomplish her personal motive. Her language itself appears to be disguised. Fourthly, Entertainment mask is used for the purpose of entertainment in theatre or opera. It can also be observed in this play Medea. Medea, the protagonist entertains herself by putting on the mask. She pacifies her anger by thinking to harm others.

The subjective function of mask in Euripides's play Medea focuses on the study of the mindset of the characters in general and the protagonist of the play Medea in particular. It helps to bring out the motifs of the play. Pirandello, a modern playwright discusses the subjective nature of mask in most of his works. According to him, 'mask is either self imposed or in most cases it is enforced on the individual by the society'. The survival of the characters is impossible without the mask. Man is no longer able to live, to function in a society either he returns to wearing his mask or becomes insane as far as the society is concerned. It reveals that mask functions in terms of subjective approach and unfold the twofold nature of reality inner and outer reality and both tend to change. The subjective function of mask can be scrutinized in the play Medea by Euripides. It involves Medea's mind. She invokes the help of the gods in order to be succeeded in her plotting of taking revenge and reveals her innerness. As she says.

MEDEA: O Zeus! O Justice, daughter of Zeus! O glorious Sun! Now I am on the road to victory; now there's hope! I shall see my enemies punished as they deserve, just where my plot was weakest, at that very point help has appeared in this man Aegeus; he is a haven. Now I tell you all my plans they will not make pleasant hearing. First I'll send a slave to Jason, asking him to come to me, then I will give him soft talk tell him he has acted well....but in my plot to kill the princess , my children must help. I'll send them to the palace bearing gifts, a dress of soft weave and a coronet of beaten gold. With such a deadly poison I'll anoint my gifts

These lines point out Medea's mind. She is preoccupied to harm others. She merely wants to kill the bride of her husband and she invokes the help of gods to be succeeded in her cunning plans of taking revenge. The motifs of revenge, plotting, hatred also come on the surface through Medea's speech. Her mask is self imposed. She masks it to give rest to her unrest nerves. She is unable to bear the betrayal of her husband and it results in various murders by her. Pirandello, the modern playwright, urges that survival is impossible without the mask and same is the case with Medea. Either she has to choose death to save herself from the agony, or to avenge on her husband in order to live. She chooses the second, putting on mask to accomplish her personal motifs. By the same token, Subjective approach of mask is found in heaps in this play Medea. 
The objective approach of mask in Euripides's play Medea entails the use of mask as a visual tool. It also helps to reveal the thematic concern of the play. Derek Walcott, a Caribbean playwright, enhances the idea of mask as a visual symbol in Dream on Monkey Mountain. According to him, 'Mask is a paralinguistic projection of a state of mind'. It includes the gestures, postures and actions of the characters to reveal their psychological state. In the play, Medea, number of images and metaphors serve this function. The dialogues spoken by Medea are replete with images which give the idea of mask being deployed by her. The conflict between inner and outer aura can be seen through her language. There is conversation between Medea and the chorus. She speaks in metaphorical language.

MEDEA: Let me work: In bitterness and pain they shall repent this marriage, repent their houses joined, and repent my banishment. Come! Lay your plan Medea; scheme with all your skill.

In her dialogue, the images of 'scheme' and 'skill' symbolize the plotting. Apparently she presents herself as innocent who is betrayed by her husband, but inwardly she is filled with detest against him. She becomes sightless. Although her husband consoles her by saying that he got married again for the sake of his children yet she censures her. The images in her discourse reflect diverse layers of mask.

In Greek mythology, Myth is a legendary or a traditional story that usually involves an event or a hero and particularly one concerning with demigods or deities and uncovers some rites, practices and natural phenomenon.

Euripides's Medea is the reworking of myth of the myth of Jason and Medea. The myth of Jason and Medea reveals the expedition of Jason who goes to Colchis in order to get the Golden Fleece and undertakes various trials. His father is imprisoned by her uncle who occupies the throne and does not want to give the property to Jason. Jason's mother pretends as if Jason has died and actually sends him away. Hera, the wife of Zeus does not like Jason's uncle and decides to punish him. She sends Jason to his uncle Pelias and forces him to demand his property. In addition, Pelias sends him to Colchis to get the Golden Fleece. If he obtains the Golden Fleece, Pelias would give him the state. Medea having magical powers helps him to obtain the golden, fleece from her father, king Aeetes. The Golden Fleece is guarded by a dragon and Medea through her magic saves Jason from the attack by the dragon. Medea elopes with Jason and both get married in Corinth. Furthermore, Euripides's Medea is the story of Jason and Medea when they have got married to each other and begin to live in Corinth.

The reworking of myth by Euripides helps to bring out the motifs of the play Medea. The protagonist, Medea deceives her father and abandons him for the sake of Jason. When Jason marries to the other woman, her wife decides to take revenge. She time and again speaks that she has left her homeland for Jason. On the other hand, Jason betrays her by marrying to another lady. So, the playwright unpacks the motifs such as revenge, betrayal and hatred through the idea of the reworking of myth.

The mytho-poetic significance of the mask showcases the myth of Jason and Medea in general and helps to uncover the motifs of the play Medea in particular. In the myth of Jason and Medea, the idea of mask can be analyzed. Medea, the magician masks the mask and deceives her father. She herself helps Jason to obtain the Golden Fleece, but she keeps it hidden from her father. At the end, she runs away with Jason. His father is surprised to see that Jason is secured from the dragon protecting the Golden Fleece. He is not aware of the help by the side of his daughter. She masks the mask in order to fulfill the personal motives. Pirandello, the modern playwright expresses that 'truth is dichotomous; personal and external'. Mask comforts to reveal the contradiction between internal and external world or conflict between illusion and reality. This can be scrutinized in the play Medea by Euripides. The conflict between appearance and reality can be observed through the conversation between Medea and Creon, the king. She disguises herself in order to deceive the king. Apparently she claims not to harm him and his daughter, but inwardly she seems to be preoccupied to avenge them. As she utters.

MEDEA: So you, Creon, are afraid- of what? Some harm that I might do to you? Don't let me alarm you, Creon. I am in no position-A woman to worng a king. You have done me no wrong. You have given your daughter to the man you chose. I hate my husband- True; but you had every right to do as you have done. So now I bear no grudge against your happiness; marry your daughter to him, and good luck to you both. But let me live in Corinth. I will bear my wrongs in silence, yielding to superior strength.

CREON: Your words are gentle; but my blood runs cold to think what plots you may be nursing deep within your heart. In fact, I trust you so much less now than before. A woman of hot temper- and a 
man the same- is a less dangerous enemy than one quiet and clever. So out you go and quickly; no more arguing. I have made my mind you are my enemy.

These lines spoken by Medea particularly enhance the dispute between appearance and reality. It can also be said that Appearances are often deceptive. She is found to be confused. She mentions that she hates her husband. On the other hand, she convinces the king not to misinterpret her as a danger to his daughter. It also conveys the sense that truth is dichotomous; personal and external. Her discourse is contrary to her innerness. She has to take revenge and she beseeches the king to let her stay in Corinth, so, she could accomplish her plan. The king tackles the situation and asks her to leave. She is trickster and manipulates language to dodge the king. After great struggle, she is succeeded. Her appearance is deceptive and opposite to the reality. It suggests the mask being masked by Medea, the protagonist of the play.

The mytho-poetic significance of the mask is of twofold in nature. On the one hand, it deals with the myth of Jason and Medea and on the other side, it entails the Greek play Medea, which is the reworking of the myth. The mythopoetic nature of mask provides the motifs of revenge, hatred, cunningness and mask.

On the other hand, Derek Walcott, the Caribbean playwright asserts that 'mask is not simply a grotesque false face worn on carnivals and rituals' rather he talks about the 'power of mask in terms of the duality of the projected and the real'. Same is the case with the myth of Jason and Medea and the reworking of myth by Euripides in form of a Greek play Medea. The mythopoetic significance of the mask in terms of the characters expresses their duality in general and the protagonist of the play Medea in particular. Medea's sole aim is to take revenge over her husband who marries other woman and she prefers to disguise herself. On the other side, Creon, the king disguises himself in order to protect his daughter who has married Jason, Medea's husband. Their plotting enhances the idea of mask in terms of duality of the projected and the real. The long conversation between Medea and Creon, the king represents their duality of the projected and the real.

MEDEA: I kneel to you, I beseech you by the younger bride, your child.

CREON: You're wasting words; you'll never make me change my mind.

MEDEA: I beg you.will you cast off pity and banish me?

CREON: I will; I have more love for my family than for you.

MEDEA: my home, my country! How my thoughts turn to you now!

CREON: I love my country too, next only to my daughter

MEDEA: Oh, what an evil power love has in people's lives

Creon: That would depend on circumstances, I imagine.

Medea: no, no, not that! But, Creon, I have one think to ask

Creon: you seemed inclined Medea to give me trouble still.

Medea: this one day let me stay to settle some plans for my exile.

These lines suggest the duality of the Creon in general and Medea in particular. Both mask the mask in order to protect themselves from the approaching danger and to fulfill the personal motives. Creon, the king of Corinth wants to save his daughter and himself from Medea's rage whereas; Medea desires to kill her enemies in order to find the solace. Their language mirrors the conflict between the projected and the real. It suggests the duality of the characters. Apparently, they justify themselves in terms of real causes but inwardly they possess mere personal motives. Firstly Creon, the king should focus on the people of his country than to his family. His language reflects his psychological state, where the love for family is found in heaps. He decides to exile Medea in order to keep his daughter save. On the other hand, apparently, Medea concerns for her children and begs one day to do some plan of her exile. Inwardly, she has intention to be succeeded in her tricks of avenging. So, Euripides's play Medea is political in nature. The conflict between desire and duty is found in great extent. The duality of the characters unpacks the dispute between appearance and reality. Derek Walcott also conveys the same. The themes of deception, cunningness, hatred and revenge are brought out through the myth of Jason and Medea in general and the play Medea in particular.

To Sum up, mask takes various shapes in Euripides's play Medea including disguise mask, protection mask, ritual mask and performance mask. These types of mask help to unmask the diverse layers of the characters in general and the protagonist of the play, Medea in particular. The Greek play Medea 
is the reworking of myth of the myth of Jason and Medea by the playwright Euripides and unfolds the motifs of the play Medea such as revenge, hatred and deception. The mythopoetic nature of the mask focuses on the use of mask in terms of subjective and objective approach respectively and presents it a sign of plurality. The researcher takes Pirandello's viewpoints of mask in order to study the character's mind and Derek Walcott's concept of mask to deal with mask as a visual tool. The researcher states that the crux of whole analysis is that people hide their real motives behind the mask.

\section{REFERENCES}

Johnstone, Keith.1981. IMPRO_improvisation and the Theatre-Mathuen Drama.

Roy, David.2015.Masks and Cultural Contexts drama education and Antropology.

Sayeed,Iffat.2014. The psycho-political Mobilization of the Mask in Dream on Monkey Mountain by Derek Walcott.

Jacobson,Amy.2011..In Hiding Behind the Mask of Contradiction: A Study of Mardi Gras and Race in New Orleans.

Jassim,Amaal.2012.Beyond the Mask : A Study in the Functions of the Mask in W.B Yeats's The Dreaming of the Bones, Luigi Pirandello's Henry IV and Jean Genet's The Blacks.

Fanon,Frantz.1952.Black Skin, White Masks. London: MacGibbon and Kee, print

Pirandello, Luigi.Six Characters in Search of an Author.

Types of Masks. https://www.google.com.pk/url?sa=t\&rct=j\&q=\&esrc=s\&source=web\&cd=12\&cad= rja\&uact=8\&ved=0ahUKEwie9pLs3L7OAhUNahoKHZ7vAlIQFghNMAs\&url=http\%3A\%2F\% 2Fwww.historyofmasks.net\%2Fmask-facts\%2Ftypes-of-masks\%2F\&usg=AFQjCNHwVia9sw UHh0lPJID169Y3-5I7dQ\&sig2=34G05oWgLwfvgyHIwXmmWQ\&bvm=bv.129422649,d.d24

Mariani,Umberto.1989. The Pirandellian Character. Canadian Journal of Italian Studies.

Dey,Soutrik. 'Behind the Curtains' with Luigi Pirandello: Constructing and 'Deconstructing': Six Characters in Search of an Author Euripides. Medea. Duke University Press.

https://journals.ku.edu/index.php/jdtc/article/viewFile/ 1713/1677

Concept of Myth. www.ancient.literature.com

\section{AuTHORS' BIOGRAPHY}

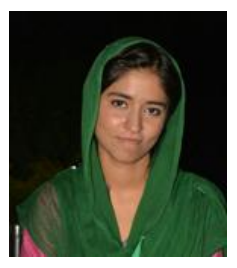

Bakhtawar Alishba, is student of BS (Hons) in English Language and Literature. Currently, she is in seventh semester. Her academic interests include Poetry, Drama, Communication skills and Modern Literature. She has written poems and short stories. She has won story telling competition. She is awarded Trophy by Pakistani Playwright Usman Ali. Recently, She has participated in two conferences. She is eager to learn more and more she is writing.

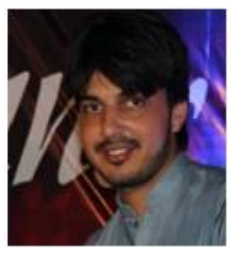

Muhammad Adnan, is lecturer in English, University of Sargodha, M.B. Din campus. He is doing M phil in English language and literature. His area of interest is Classical Literature. His thesis is on Pakistani Folk Tales 